\title{
PENGEMBANGAN MEDIA BELAJAR BERBASIS DESKTOP UNTUK MENGENAL KEARIFAN LOKAL DAN DESTINASI WISATA KALIMANTAN SELATAN
}

\author{
Ahmad Rusadi ${ }^{1}$, Kenti Yuliana ${ }^{2}$, \& M. Rizki Zulkarnain ${ }^{3}$
}

1. Program Studi Pendidikan Teknologi Informasi STKIP PGRI Banjarmasin Ahmadrusadi1795@gmail.com (085392190777)

2. Program Studi Pendidikan Teknologi Informasi STKIP PGRI Banjarmasin kentiyuliana@gmail.com (081349590042)

3. Program Studi Pendidikan Teknologi Informasi STKIP PGRI Banjarmasin jurnal.rizkizulkarnain@gmail.com(085233336969)

\begin{abstract}
ABSTRAK
Kearifan lokal adalah modal masyarakat untuk memadukan aspek kelestarian alam dengan aspek perekonomian. Potensi yang banyak dimiliki daerah di Indonesia adalah potensi alam, karena keindahan dan keunikannya dapat dikembangkan. Dengan memperkenalkan destinasi wisata yang dimiliki Kalimantan Selatan, maka akan berdampak baik terhadap daerah tersebut dan masuk dalam daftar rencana tujuan wisata, menciptakan lapangan kerja dan meningkatnya perekonomian daerah setempat (Kelurahan, desa, kecamatan, kabupaten, provinsi). Berdasarkan latar belakang tersebut, maka tujuan dalam penelitian ini adalah mengembangkan media belajar mandiri berbasis desktop untuk mengenal kearifan lokal dan destinasi wisata Kalimantan Selatan agar layak digunakan sebagai media untuk lebih memperkenalkan wisata yang ada di Kalimantan Selatan. Penelitian yang digunakan adalah Penelitian dan Pengembangan (Research and Development/R\&D) dengan mengadaptasi model Alessi \& Trollip yang terdiri dari 3 tahap yaitu: planning (perencanaan), design (perancangan) dan development (pengembangan). Instrumen pengumpulan data yang digunakan adalah lembar validasi ahli materi, ahli media, uji coba perorangan, dan uji coba lapangan. Hasil dari penelitian ini adalah Penilaian ahli materi rata-rata 4,4 dengan kategori "Sangat Baik". Penilaian ahli media rata-rata 4,13 dengan kategori "Sangat Baik". Penilaian uji coba perorangan rata-rata 4,75 dengan kategori "Sangat Baik". Penilaian uji coba lapangan rata-rata skor 4,45 dengan kategori "Sangat Baik". Kesimpulan dari penelitian ini adalah dihasilkannya sebuah media belajar yang layak untuk digunakan sebagai media pengenalan wisata yang ada di Kalimantan Selatan.
\end{abstract}

Kata Kunci: Media Belajar, Kearifan Lokal, Destinasi Wisata

\section{PENDAHULUAN}

Perkembangan Teknologi saat ini sudah banyak dimanfaatkan sebagai salah satu cara untuk mempermudah memperoleh informasi. Dalam era globalisasi, perkembangan teknologi informasi di Indonesia berjalan cukup pesat. Globalisasi yang diartikan suatu proses menyatunya dunia yang meliputi berbagai bidang tata kehidupan dunia mengandung karakteristik adanya perubahan keterbukaan, kreativitas, kecanggihan, kecepatan, keterikatan, keunggulan, kekuatan dan kompetisi bebas (Tjokronegoro, 2000). Sebagai salah satu bidang yang mempersiapkan sumberdaya manusia, dunia pendidikan dituntut untuk 
mengkonversikan tacit knowledge yang merupakan pengetahuan yang lahir berdasarkan pengalaman asli (learn by experience) dengan memasukkan elemenelemen iptek modern sehingga menjadi explisit knowledge yang menghasilkan produk-produk baru sesuai dengan state of the art mutakhir dan kompetitif (Zuhal, 2000). Salah satunya peran teknologi yang dapat kita manfaatan yaitu di dalam bidang Kearifan Lokal dan Destinasi Wisata. Pada penelitian ini dikembangkan aplikasi media belajaran Mandiri Berbasis Desktop Untuk Mengenal Kearifan Lokal Dan Destinasi Wisata Kalimantan Selatan, pada penelitian ini akan ditujukan kepada promosi dan sosialisasi destinasi wisata kemasyarakat kota sampai ke masyarakat pedesaan terpencil dan tidak semua daerah yang akan disosialisasikan terjangkau jaringan internet sehingga peneliti mengembangkan media belajar berbasis desktop menjadikan seluruh konten dari aplikasi dapat terpusat pada satu aplikasi saja serta tidak memerlukan koneksi internet. Penelitian ini mengadaptasi model pengembangan menurut Alessi \& Trollip yang dikhususkan untuk pengembangan multimedia interaktif salah satunya berupa Hypermedia (Alessi, \& Trollip, 2001: 10). Dengan menggunakan pengembangan media belajar ini, diharapkan pengguna lebih tertarik untuk belajar mengenal Kearifan Lokal dan Destinasi Wisata Kalimantan Selatan melalui laptop maupun komputer.

Media adalah suatu sarana yang dapat digunakan untuk menyampaikan informasi kepada siswa. Media berasal dari bahasa Latin dan merupakan bentuk jamak dari kata "Medium" yang secara harfiah berarti "perantara" yaitu perantara sumber pesan (a source) dengan penerima pesan (a receiver) (Heinich, dkk dalam Hermawan, 2007: 3). Oleh karena itu, media dapat diartikan sebagai perantara atau pengantar pesan dari pengirim ke penerima pesan. Media dapat berupa sesuatu bahan (software) dan/atau alat (hardware). Menurut Gerlach \& Ely (dalam Arsyad, 2002), mengatakan bahwa media jika dipahami secara garis besar adalah manusia, materi, atau kejadian yang membangun kondisi, yang menyebabkan siswa mampu memperoleh pengetahuan, keterampilan, atau sikap. Jadi menurut pengertian ini, guru, teman sebaya, buku teks, lingkungan sekolah dan luar sekolah, bagi seorang siswa merupakan media.

Kemandirian merupakan kemampuan seseorang untuk tidak bergantung pada orang lain. Hamzah B. Uno (2010: 77-78) mendefinisikan kemandirian sebagai kemampuan untuk mengendalikan diri sendiri dalam berpikir dan bertindak. Belajar mandiri merupakan proses belajar siswa yang timbul dari dalam diri siswa itu sendiri karena ingin mencapai tujuan yang diinginkan, hal tersebut sesuai dengan pendapat Mudjiman (2007: 7). Pada penelitian ini, kemampuan belajar mandiri yang dimiliki oleh pebelajar didefinisikan sebagai kemampuan untuk berinisiatif dalam mengatur (regulate), mengelola dan mengontrol proses belajarnya untuk mengatasi berbagai masalah dalam belajar dengan mempergunakan berbagai alternatif atau strategi belajar (Jarvis, 1990). Kata kunci dari belajar mandiri adalah adanya "inisiatif' atau sikap "proaktif' dari seseorang untuk mengelola belajarnya (Hiemstra, 1998; Knowles, 1975).

Disadari bahwa pariwisata Kalsel masih perlu dipoles agar bisa menggeliat dan menjadi destinasi wisata domestic serta internasional. Menggelorakan sektor pariwisata Kalsel, Gubernur Kalsel H Sahbirin Noor mengajak semua pihak untuk berperan dengan bergerak bersama-sama."Mari kita bergerak agar wisata Kalsel menuju dunia. Apalagi kita akan punya bandara internasional yang menjadi pintu 
masuk wisatawan. Barengi pula dengan sikap yang ramah terhadap wisatawan," ujarnya saat membuka Kalsel Travel Fair 2018, Jumat (2/3/2018).

Salah satu upaya yang dilakukan Pemerintah Provinsi Kalimantan Selatan untuk meningkatkan perekonomian masyarakat melalui promosi sektor pariwisata. Objek wisata Pasar Terapung dan wisata alam Loksado merupakan sebagian objek wisata andalan Kalsel. Promosi tentang potensi pariwisata di Kalsel juga dilakukan Sekretaris Daerah Provinsi Kalsel, Haris Makkie, saat menerima kunjungan kerja Peserta Diklatpim II Provinsi Jawa Timur Angkatan 45 Tahun 2017, beberapa waktu lalu. "Pemprov Kalsel terus mendorong pengembangan sektor pariwisata guna meningkatkan ekonomi masyarakat. Kita punya banyak potensi wisata yang bisa dijual," tutur Haris saat ditemui di Banjarmasin, Jumat (23/6).

Kearifan lokal ialah modal utama masyarakat dalam membangun dirinya tanpa merusak tatanan sosial yang adaptif dengan lingkungan alam sekitarnya. Kearifan lokal dibangun dari nilai-nilai sosial yang dijunjung dalam struktur sosial masyarakat sendiri dan memiliki fungsi sebagai pedoman, pengontrol, dan ramburambu untuk berperilaku dalam berbagai dimensi kehidupan baik saat berhubungan dengan sesama maupun dengan alam.

Kearifan lokal dalam beberapa dasawarsa terakhir ini mendapatkan perhatian besar dari berbagai kalangan terutama lembaga-lembaga swadaya masyarakat dan pemerhati lingkungan. Beberapa pemerintah daerah pun mulai menggali kearifan lokal yang dimiliki daerahnya. Ketertarikan ini disebabkan karena semakin dominannya dampak dari modernisasi yang melahirkan konsekuensi-konsekuensi yang merugikan. Konsekuensi dari eksploitasi sumber daya alam yang tak terkendali akan mengakibatkan degradasi lingkungan hidup, tidak terkecuali lingkungan laut. Arus modernisasi dan globalisasi yang melanda setiap daerah sampai ke pelosok-pelosok negeri, menjadikan pembuat kebijakan dan para pemerhati lingkungan mencoba berbagai cara meminimalisasi kemungkinan dampak yang muncul. Salah satu harapan tertumpu pada kearifankearifan terhadap lingkungan yang dimiliki oleh masing-masing daerah. Kearifan lokal diharapkan dapat mengatasi ancaman degradasi lingkungan karena kearifan lokal merupakan dimensi budaya dan sosial yang lahir dalam kehidupan bermasyarakat yang telah berlangsung secara turun temurun. Kearifan lokal dapat menjelma dalam berbagai bentuk seperti ide, gagasan, nilai, norma dan peraturan dalam ranah kebudayaan, sedangkan dalam kehidupan sosial dapat berupa sistem religius, sistem dan organisasi kemasyarakatan, sistem pengetahuan, sistem mata pencaharian hidup, dan sistem teknologi dan peralatan (Koentjaraningrat, 1964). Identifikasi kearifan lokal masyarakat nelayan harus lebih difokuskan kepada permasalahan yang menyangkut isu global dan sekaligus mempunyai pengaruh yang cukup besar bagi keberlangsungan hidup masyarakat local (Coremap, 2005).

Sekarang eksistensi kearifan lokal dirasakan semakin memudar pada berbagai kelompok masyarakat. Salah satu kelompok masyarakat yang paling rawan mengalami pelunturan kearifan lokal adalah komunitas petani tepian hutan, yang semestinya sebagai penyangga sosial bagi upaya konservasi hutan dan kelestarian sumber daya hutan.

Kearifan lokal ialah satu dari modal masyarakat untuk memadukan aspek kelestarian alam dengan aspek pemenuhan ekonomi yang dikonsep sebagai ekowisata. Satu dari potensi yang banyak dimiliki daerah-daerah di Indonesia 
adalah potensi alam yang karena keindahan dan keunikannya dapat dikembangkan untuk ekowisata. Korelasi yang sangat erat antara kearifan lokal dan ekowisata ialah kearifan lokal masyarakat tertentu biasanya berkaitan dengan caranya berhubungan dengan lingkungan dan alam sekitar. Interaksi kearifan tersebut ialah daya tarik yang sangat bagus untuk dikemas menjadi konsep ekowisata yang unik.

Sehubungan dengan pengenalan kearifan lokal dan destinasi wisata Kalimantan Selatan, kita sebagai masyarakat tidak boleh mengabaikannya begitu saja potensi wisata di daerah kita, tetapi kita sebagai masyarakat harusnya lebih peka terhadap masalah ini. Karena dengan mengembangkan media pengenalan kearifan lokal dan destinasi ini diharapkan bisa menarik minat untuk mengenal tujuan wisata dan mengembangkan ekonomi daerah Kalimantan Selatan sendiri melalui media tersebut. Peran media ini sebagai fasilitator dalam memberikan media belajar mandiri kepada anak maupun orang dewasa.

\section{METODE PENELITIAN}

\section{A. Prosedur Penelitian dan Pengembangan}

Prosedur Pengembangan yang digunakan adalah pengembangan model Alessi \& Trollip (Alessi, \& Trollip, 2001, pp. 411-412) terdiri dari planning (perencanaan), design (perancangan), dan development (pengembangan).

\section{Tahap planning (perencanaan)}

Tahapan planning (perencanaan) meliputi; (1) penentuan ruang lingkup, dimana langkah ini melibatkan target pengguna untuk menentukan kebutuhan; (2) mengidentifikasi karakteristik pengguna untuk memastikan agar konten yang akan disajikan dalam konteks yang tepat; (3) menetapkan hambatan-hambatan yang terjadi seperti adanya kendala; (4) memperkirakan biaya dalam pembuatan produk dengan membuat anggaran; (5) membuat dokumen perencanaan; (6) menentukan dan mengumpulkan sumber-sumber; (7) melakukan diskusi ide awal; (8) menetapkan rencana tampilan dengan berkonsultasi de-ngan klien untuk menciptakan tampilan yang sesuai; (9) mendapatkan persetujuan dari penggunan memungkinkan waktu untuk persetujuan dan revisi. Dari ruang lingkup tersebut dapat diamati melalui dua aspek, yaitu: (1) identifikasi aspek proses pembelajaran; (2) identifikasi aspek media pembelajaran yang sesuai.

\section{Tahap design}

Tahapan design (perancangan) meliputi: (1) mengembangkan ide-ide; (2) melakukan analisis konsep dan tugas untuk mengekplorasi informasi yang didesain pada produk menterjemahkan analisis konsep produk awaldengan mendeskripsikan tata letak, urutan, dan karakteristik produk; (4) membuat flowchart, layout, dan storyboard untuk menunjukkan alur program langkah demi langkah; (5) menentukan tampilan desain; (6) persetujuan dari klien tentang desain produk; (7) evaluasi dan revisi kualitas produk selama tahapan desain. Dari beberapa tahap proses perancangan diatas dapat dikelompokkan menjadi dua proses, yaitu; (1) pengumpulan referensi yang dibutuhkan berupa bahan ajar dan materi pembelajaran yang akan diintegrasikan dalam media pembelajaran yang disesuaikan dengan indikator pembelajaran yang interaktif, inspiratif dan menyenangkan; (2) perancangan media pembelajaran I2M pada pembelajaran animasi stop motion. 


\section{Tahap development (pengembangan)}

Tahapan development (pengembangan) meliputi: (1) mempersiapakan teks; (2) menggabungkan bagian-bagian; (3) menyiapkan materi-materi pendukung seperti petunjuk belajar untuk siswa dan instruktur, pedoman teknis, materi pembelajaran dan software; (4) pembuatan program; (5) melakukan uji alpha dan melakukan revisi awal; (6) melakukan uji beta dan membuat revisi akhir; (7) uji coba dan melakukan evaluasi sumatif.

Data yang diperoleh melalui kegiatan uji coba diklasifikasikan menjadi dua, yaitu data kualitatif dan data kuantitatif. Data kualitatif berupa kritik dan saran yang dikemukakan ahli materi dan ahli media, dihimpun untuk memperbaiki produk media belajar berbasis hypermedia atau multimedia. Data kuantitatif yang diperoleh dari kuisioner selanjutnya dikonversikan ke data kualitatif dengan skala 5 (skala likert) menurut ketentuan Sugiyono (2012:329-333) dapat dilihat pada tabel 1 .

Tabel 1. Konversi data kuantitatif ke data kualitatif.

\begin{tabular}{|c|c|c|c|}
\hline $\begin{array}{c}\text { Data } \\
\text { Kuantitatif }\end{array}$ & Rentang & \multicolumn{2}{|c|}{ Data Kualitatif } \\
\hline 5 & $\mathrm{X}>\mathrm{Xi}+1,50 \mathrm{Sbi}$ & Sangat Baik & $\mathrm{SB}$ \\
\hline 4 & $\mathrm{Xi}+0,50 \mathrm{Sbi}<\mathrm{X} \leq \mathrm{Xi}+1,50 \mathrm{Sbi}$ & Baik & $\mathrm{B}$ \\
\hline 3 & $\mathrm{Xi}-0,50 \mathrm{Sbi}<\mathrm{X} \leq \mathrm{Xi}+0,50 \mathrm{Sbi}$ & Cukup & $\mathrm{C}$ \\
\hline 2 & $\mathrm{Xi}-1,50 \mathrm{Sbi}<\mathrm{X} \leq \mathrm{Xi}-1,50 \mathrm{Sbi}$ & Kurang & $\mathrm{K}$ \\
\hline 1 & $\mathrm{X} \leq \mathrm{Xi}-1,50 \mathrm{Sbi}$ & Sangat Kurang & $\mathrm{SK}$ \\
\hline
\end{tabular}

Keterangan :

$$
\begin{aligned}
\mathrm{Xi} & =\text { Rerata Ideal } \\
& =1 / 2(\text { skor max }+ \text { skor min }) \\
\mathrm{Sbi} & =\text { Simpangan Baku Ideal } \\
& =1 / 6(\text { skor max }- \text { skor min }) \\
\mathrm{X} & =\text { Skor Aktual }
\end{aligned}
$$

Berdasarkan perhitungan diatas maka didapatkan pedoman hasil konversi skor untuk menentukan kriteria tingkat tingkat kelayakan media yang disajikan pada tabel 2 .

Tabel 2. Pedoman hasil konversi skor

\begin{tabular}{|c|c|c|c|}
\hline $\begin{array}{c}\text { Data } \\
\text { Kuantitatif }\end{array}$ & Rentang & \multicolumn{2}{|c|}{ Data Kualitatif } \\
\hline 5 & $\mathrm{X}>4,01$ & Sangat Baik & SB \\
\hline 4 & $3,34<\mathrm{X} \leq 4,01$ & Baik & $\mathrm{B}$ \\
\hline 3 & $2,66<\mathrm{X} \leq 3,34$ & Cukup & $\mathrm{C}$ \\
\hline 2 & $1,99<\mathrm{X} \leq 2,66$ & Kurang & $\mathrm{K}$ \\
\hline 1 & $\mathrm{X} \leq 1,99$ & Sangat Kurang & $\mathrm{S}$ \\
\hline
\end{tabular}

Menghitung rata-rata tiap aspek dengan rumus berikut (Sukardjo dalam Wibowo \& Nugroho, 2015):

Keterangan :

$\mathrm{X}=$ Skor rata-rata

$\sum \mathrm{X}=$ Jumlah Skor

$\mathrm{N} \quad=$ Jumlah Indikator 
Dalam penelitian ini, ditetapkan nilai kelayakan produk dari ahli materi, ahli media, uji coba perorangan dan uji coba lapangan dengan rentang rata-rata "3,34 $<\mathrm{X} \leq 4,01$ " dengan kategori "Baik". Menurut Sugiyono (2012) Jika telah didapat hasil penilaian akhir secara keseluruhan dengan minimal kategori "Baik", maka produk hasil pengembangan tersebut sudah layak digunakan sebagai bahan ajar.

Tampilan dan pembahasan media belajar hasil penelitian dan pengembangan terdiri dari beberapa bagian diantaranya:

\section{Tampilan Halaman Awal (Cover)}

Desain halaman awal pada media belajar ini terdiri dari judul media belajar terdapat ditengah halaman, ditengah nya terdapat tombol play untuk memulai media.

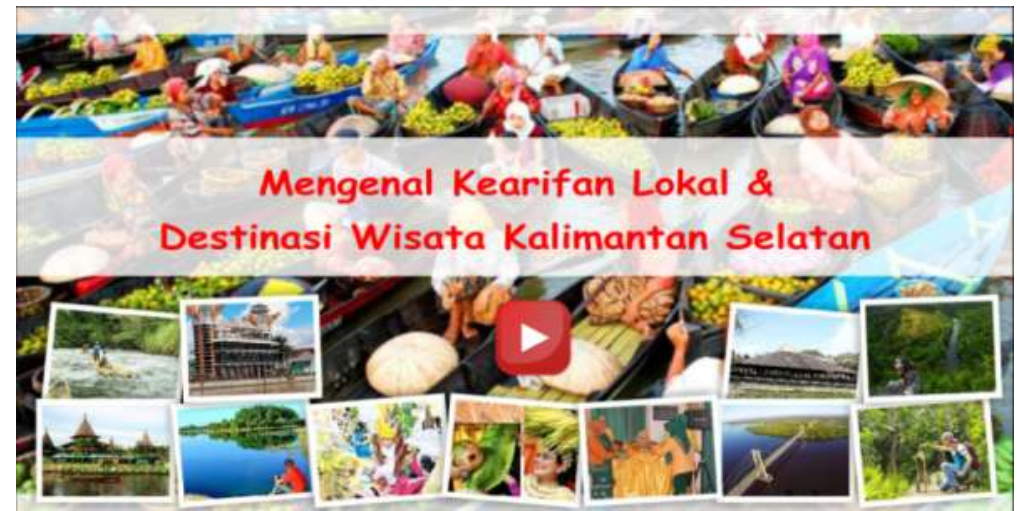

Gambar 1. Tampilan halaman awal (cover).

\section{Tampilan Menu Utama}

Desain halaman menu utama ini terdiri dari tombol Kearifan Lokal, Destinasi wisata, Kuis dan Profil selain itu juga terdapat tombol navigasi yang terletak pada bagian pojok kanan atas ada terdapat navigasi pilih musik backsound, home dan keluar dari program.

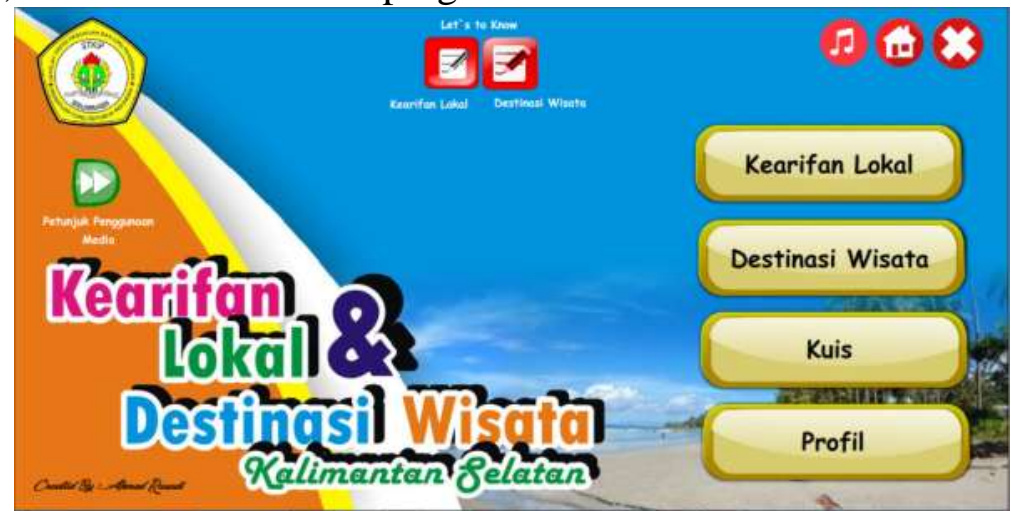

Gambar 2. Tampilan menu utama.

\section{Desain Halaman Menu Kearifan Lokal}

Pada halaman ini terdapat tombol dan gambar kearifan lokal yang akan menjelaskan tentang kearifan lokal yang di pilih, selain itu juga terdapat tombol navigasi yang terletak pada bagian pojok kanan atas ada terdapat navigasi pilih musik backsound, home dan keluar dari program. 


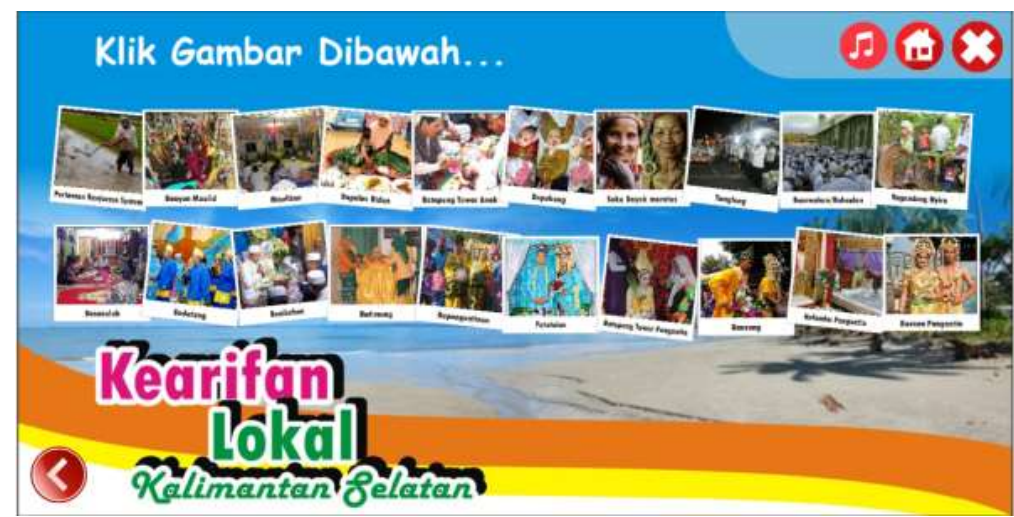

Gambar 3. Desain halaman menu kearifan lokal.

\section{Desain Halaman Menu Kabupaten Destinasi Wisata}

Pada halaman ini anda akan menampilkan 13 tombol kabupaten yang ada di Kalimantan Selatan dan logo tersebut bisa dipilih untuk menampilkan informasi destinasi, selain itu juga terdapat tombol navigasi yang terletak pada bagian pojok kanan atas ada terdapat navigasi pilih musik backsound, home dan keluar dari program.

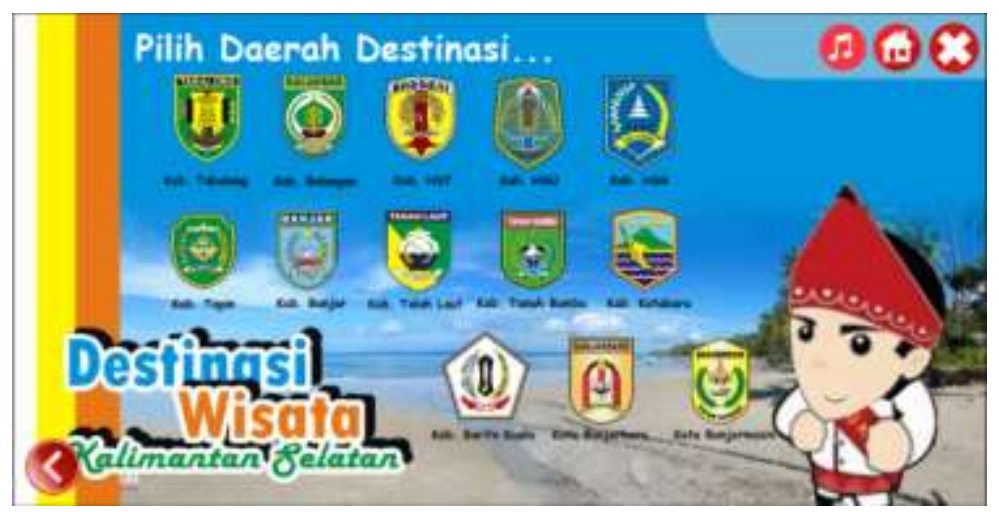

Gambar 4. Desain halaman menu kabupaten destinasi wisata

\section{Desain Halaman Kuis}

Pada halaman ini terdapat 3 pilihan tombol yaitu tombol Kuis, Kearifan Lokal, Destinasi Wisata dan Tebak Gambar, selain itu juga terdapat tombol navigasi yang terletak pada bagian pojok kanan atas ada terdapat navigasi pilih musik backsound, home dan keluar dari program.

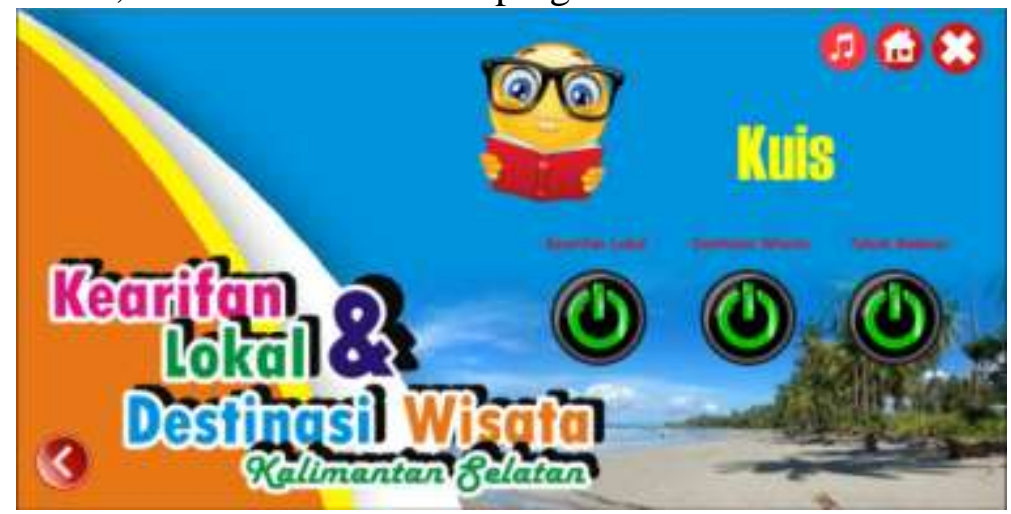

Gambar 5. Desain Halaman Menu Kuis 


\section{B. Penyajian Data Uji Coba}

Penyajian data dalam penulisan ini terdiri dari 2 macam, yaitu penyajian data hasil validasi ahli dan penyajian data hasil uji coba lapangan. Penyajian data hasil validasi ahli dan uji coba lapangan ini diperoleh dari lembar validasi.

\section{Uji Alpha}

Pengujian alpha berlangsung di situs pengembang oleh tim internal, sebelum rilis kepada pelanggan eksternal hal ini khusus digunakan oleh organisasi pengembangan produk dengan tujuan agar sistem yang dikembangkan terhindar dari cacat atau kegagalan penggunaan.

\section{Hasil Validasi Ahli Media}

Aspek penilaian untuk ahli materi di tinjau dari aspek (1) Pemrograman dan (2) Tampilan. Hasil validasi dan penilaian dua orang ahli media dari Dosen Program Studi Pendidikan Teknologi Informasi STKIP PGRI Banjarmasin dapat disajikan pada tabel 3.

Tabel 3. Hasil validasi ahli media.

\begin{tabular}{|c|c|c|c|c|c|c|c|}
\hline \multirow{2}{*}{$\begin{array}{c}\text { Aspek } \\
\text { Penilaian }\end{array}$} & \multirow[b]{2}{*}{$\sum$ Indikator } & \multicolumn{2}{|c|}{ Validator I } & \multicolumn{2}{|c|}{ Validator II } & \multirow{2}{*}{$\begin{array}{l}\text { Rata- } \\
\text { rata }\end{array}$} & \multirow[b]{2}{*}{ Kategori } \\
\hline & & $\sum_{\text {Skor }}$ & $\begin{array}{l}\text { Rata } \\
\text {-rata } \\
\end{array}$ & $\sum_{\text {Skor }}$ & $\begin{array}{l}\text { Rata } \\
\text {-rata } \\
\end{array}$ & & \\
\hline Pemrograman & 8 & 34 & 4,25 & 36 & 4,5 & 4,37 & Sangat Baik \\
\hline Tampilan & 11 & 44 & 4 & 42 & 3,81 & 3,90 & Baik \\
\hline \multicolumn{6}{|c|}{ Rata-rata } & 4.13 & Sangat Baik \\
\hline
\end{tabular}

\section{Hasil Validasi Ahli Materi}

Aspek penilaian untuk ahli materi di tinjau dari aspek isi. Hasil validasi dan penilaian dua orang ahli materi dari Kabid \& staff Pariwisata Hulu Sungai Tengah dapat disajikan pada tabel 4.

Tabel 4. Hasil validasi ahli materi

\begin{tabular}{|c|c|c|c|c|c|c|c|}
\hline \multirow{2}{*}{$\begin{array}{c}\text { Aspek } \\
\text { Penilaian }\end{array}$} & \multirow[b]{2}{*}{ ¿Indikator } & \multicolumn{2}{|c|}{ Validator I } & \multicolumn{2}{|c|}{ Validator II } & \multirow{2}{*}{$\begin{array}{l}\text { Rata- } \\
\text { rata }\end{array}$} & \multirow[b]{2}{*}{ Kategori } \\
\hline & & $\sum_{\text {Skor }}$ & $\begin{array}{l}\text { Rata } \\
\text {-rata }\end{array}$ & $\sum_{\text {Skor }}$ & $\begin{array}{l}\text { Rata } \\
\text {-rata }\end{array}$ & & \\
\hline Isi & 10 & 44 & 4,4 & 44 & 4,4 & 4,4 & Sangat Baik \\
\hline \multicolumn{6}{|c|}{ Rata-rata } & 4,4 & Sangat Baik \\
\hline
\end{tabular}

\section{Uji Beta}

Pengujian beta juga dikenal sebagai pengujian pengguna berlangsung di lokasi pengguna akhir oleh pengguna akhir untuk memvalidasi kegunaan, fungsi, kompatibilitas, dan uji reliabilitas dari software yang dibuat. Hal ini juga dikenal sebagai uji lapangan. Ini terjadi di lokasi pelanggan. Ini mengirimkan sistem untuk pengguna yang menginstal dan menggunakannya di bawah kondisi kerja dunia nyata. Tes beta merupakan tahap kedua dari pengujian perangkat lunak di mana pengguna mencoba produk. 


\section{Hasil Uji Coba Perorangan}

Uji coba perorangan terhadap media belajar ini dilakukan oleh Kabid dan staff pariwisata Hulu Sungai Tengah bertindak menjadi responden sebagai promotor wisata. Hasil uji coba perorangan disajikan pada tabel 5.

Tabel 5. Hasil Uji Coba Perorangan.

\begin{tabular}{|c|c|c|c|c|c|c|c|}
\hline \multirow{2}{*}{$\begin{array}{c}\text { Responden } \mathrm{Uji}_{\mathrm{ji}} \\
\text { Coba }\end{array}$} & \multirow[b]{2}{*}{ SIndikator } & \multicolumn{2}{|c|}{ Responden I } & \multicolumn{2}{|c|}{ Responden II } & \multirow{2}{*}{$\begin{array}{l}\text { Rata- } \\
\text { rata }\end{array}$} & \multirow[b]{2}{*}{ Kategori } \\
\hline & & $\sum_{\text {Skor }}$ & $\begin{array}{l}\text { Rata } \\
\text {-rata }\end{array}$ & $\sum_{\text {Skor }}$ & $\begin{array}{l}\text { Rata- } \\
\text { rata }\end{array}$ & & \\
\hline Promotor wisata & 10 & 48 & 4,8 & 47 & 4,7 & 4,75 & $\begin{array}{l}\text { Sangat } \\
\text { Baik }\end{array}$ \\
\hline \multicolumn{6}{|c|}{ Rata-rata } & 4,75 & $\begin{array}{l}\text { Sangat } \\
\text { Baik }\end{array}$ \\
\hline
\end{tabular}

\section{Hasil Uji Coba Lapangan}

Uji coba lapangan dilaksanakan kepada responden yang berlatar belakang pengajar, pegawai dan mahasiswa karena untuk media yang dikembangkan untuk semua kalangan. Hasil ujicoba lapangan disajikan pada tabel 6.

Tabel 6. Hasil uji coba lapangan.

\begin{tabular}{|c|c|c|c|c|}
\hline $\begin{array}{c}\text { Responden Uji } \\
\text { Coba }\end{array}$ & Indikator & $\sum$ Skor & Rata-rata & Kategori \\
\hline Responden I & \multirow{5}{*}{18} & 82 & 4,55 & Sangat Baik \\
\hline Responden II & & 78 & 4,33 & Sangat Baik \\
\hline Responden III & & 85 & 4,72 & Sangat Baik \\
\hline Responden IV & & 84 & 4,66 & Sangat Baik \\
\hline Responden V & & 72 & 4 & Baik \\
\hline \multicolumn{3}{|c|}{ Rata-rata } & 4,45 & Sangat Baik \\
\hline
\end{tabular}

\section{Evaluasi Sumatif}

Evaluasi sumatif adalah evaluasi yang dilakukan pada setiap akhir satu satuan waktu yang didalamnya tercakup lebih dari satu pokok bahasan, dan dimaksudkan untuk mengetahui sejauh mana program telah dapat berpindah dari suatu unit ke unit berikutnya.

Tabel 7. Evaluasi Sumatif.

\begin{tabular}{|c|c|c|c|}
\hline Unit & $\begin{array}{c}\text { Validator/ } \\
\text { Responden }\end{array}$ & Rata-rata & Kategori \\
\hline Ahli Media & 2 & 4,13 & Sangat Baik \\
\hline Ahli Materi & 1 & 4,4 & Sangat Baik \\
\hline $\begin{array}{c}\text { Uji Coba } \\
\text { Perorangan } \\
\text { Uji Coba } \\
\text { Lapangan }\end{array}$ & 1 & 4,75 & Sangat Baik \\
\hline \multicolumn{2}{|c|}{ JUMIAH } & 4,45 & Sangat Baik \\
\hline
\end{tabular}




\section{A. Simpulan}

\section{SIMPULAN \& SARAN}

Kesimpulan dari hasil penelitian dan pengembangan Produk media belajar mengenal kearifan lokal dan destinasi wisata Kalimantan Selatan berdasarkan hasil akhir nilai kelayakan media ini layak digunakan sebagai bahan belajar.

\section{B. Saran}

Berdasarkan penelitian dan pengembangan ini, maka dapat disarankan halhal sebagai berikut :

1. Media belajar interaktif berbasis Macromedia Flash hasil pengembangan ini dapat digunakan untuk pengenalan kearifan dan destinasi wisata Kalimantan selatan di Dinas yang terkait.

2. Mengingat hasil produk penelitian dan pengembangan dapat memberi manfaat untuk pengenalan potensi daerah, maka disarankan kepada promotor wisata untuk mengembangkan produk ini dengan cakupan yang lebih luas ataupun pada potensi wisata lainnya yang ada di Kalimantan Selatan yang belum masuk dalam media yang dikembangkan ini.

\section{DAFTAR RUJUKAN}

Fajariani, U. (2015). Peranan kearifan lokal dalam pendidikan karakter. Jurnal sosio didaktika,1,123-130.

Ismalik \& Eko. (2016). Pengembangan multimedia pembelajaran praktik individu instrument pokok dasar siswa SMK di bidang keahlian karawitan. Jurnal Pendidikan Vokasi,6,173-183.

Kurniasari, N., \& Reswati, E.(2011). Kearifan lokal masyarakat Lamalera. Jurnal bulletin riset sosek kelautan dan perikanan,6,29-33.

Muin, A.(2017). Keterampilan berbasis multimedia interaktif pada pembelajaran seni budaya di sekolah dasar.Jurnal penelitian pendidikan INSANI, 20,133-135.

Musfiqon \& Widodo (2015). Desain Presentasi Pembelajaran Inovatif. Jakarta Prestasi

Prasetya, AE., \& Surjono, HD.(2017). Pengembangan media pembelajaran interaktif, inspiratif dan menyenangkan (I2M) pada materi animasi stop motion, Journal of vocational and work education, 1, 26-35.

Purnomo, AP., Pratisto, EH,. Taufiqurrakhman,. Sahrul, F., \& Lestari, IP.(2016). Pembuatan game edukasi "petualangan si gemul" sebagai pembelajaran pengenalan daerah Solo Raya pada anak. Jurnal Simetris, 7,619-626.

Putra, RA., Kamil, M., \& Pramudia, JR.(2017). Penerapan pembelajaran mandiri dalam meningkatkan hasil belajar peserta didik. jurnal antalogi pendidikan luar sekolah, 1, 24-36.

Ready, R. (2000). Mothers' personality and its interaction with child temperament as predictors of parenting behavior. Journal of Personality and Social Psychology, 79, 274-285.

Rohman, A., Wahyu, D., Arifin, M., \& Wibawa, AP. (2015). Jelajah Indonesia menggunakan teknologi android (jelita): aplikasi game pembangun karakter anak bangsa. Prosiding sentia, 7, 65-70.

Satya, AP., Siddiq, FR., Pratama, RA, Hidayati, H., \& Gozali, AA.(2015). Permainan edukasi pariwisata pulau Jawa berbasis android. Journal eproceeding of applied science, 1 . 
Sugianti, D.(2016). Strategi pengembangan kawasan wisata pasar terapung berbasis kearifan lokal di Kota Banjarmasin. Jurnal tata kelola seni,2,2034.

Wibowo, EJ. (2013). Media pembelajaran interaktif matematika untuk siswa sekolah dasar kelas IV. Jurnal seminar riset unggulan nasional informatika dan computer FTI UNSA, 2.

Yuniati, N., Purnama, BE., \& Nugroho, GK. (2011). Pembuatan Media Pembelajaran interaktif ilmu pengetahuan alam pada sekolah dasar Negeri Kroyo 1 Sragen. Journal Speed - sentra penelitian engineering dan edukasi, 3,25-29.

Zulharman., Junaidin., Khaldun, I., \& Santoso, H.(2017). Kearifan lokal masyarakat desa Sambori dalam pengelolaan sumber daya alam dan potensi ekowisata. Jurnal ilmiah mandala education,3,189-198. 